\title{
METAMORPHIC DEVELOPMENT OF CORDIERITE-BEARING LAYERED SCHIST AND MICA SCHIST IN THE VICINITY OF SAVONRANTA, EASTERN FINLAND
}

\author{
N. M. HALDEN and D. R. BOWES
}

\begin{abstract}
HALDEN, N. M. and BOWES, D. R., 1984: Metamorphic development of cordierite-bearing layered schist and mica schist in the vicinity of Savonranta, eastern Finland. Bull. Geol. Soc. Finiand 56, Part 1-2, 3-23.

The sequential development of minerals in polyphase deformed schists of the Savonranta district can be demonstrated in a limited number of lithologies. Cordierite-bearing and micaceous schists are used to established a polymetamorphic history within an area where field mapping and structural studies have provided a basis for the erection of temporal relations of metamorphic fabric elements. Coexisting phases whose relative times of development have been established were selected for microprobe analysis and their compositions used in a quantitative thermodynamic study to determine temperatures and pressures of successive metamorphic events.

Conditions deduced for the phase of metamorphism $\left(\mathrm{M}_{1}\right)$ associated with the $\mathrm{D}_{1}$ deformational phase are $c .550^{\circ} \mathrm{C}$ and $3 \mathrm{~kb}$. The peak of metamorphism, during $\mathrm{M}_{2}-\mathrm{D}_{2}$ was at c. $700^{\circ} \mathrm{C}$ and $7.5 \mathrm{~kb}$. Conditions for an $\mathrm{M}_{3}$ metamorphic event of $c .300^{\circ} \mathrm{C}$ and $2-3 \mathrm{~kb}$ are estimated from mineral assemblages in $\mathrm{P}-\mathrm{T}$ space, not from mineral compositions. A late thermal event $\left(\mathrm{M}_{\mathrm{L}}{ }^{\prime}\right)$ is related to the emplacement of porphyritic granite: $c .600^{\circ} \mathrm{C}$ and $4 \mathrm{~kb}$ are estimated from mineral assemblages in $\mathrm{P}-\mathrm{T}$ space.

A single outcrop of a layered schist, which is unique to the district, is interpreted as a tectonic slice from a deeper crustal level. It provides evidence of a low $P$, high $T$ granulite facies metamorphic event $\left(M_{\text {EARLY }}\right)$ pre-dating $M_{1}-D_{1}$.
\end{abstract}

Key words: Metamorphism, Svecokarelides, deformation.

N. M. Halden: Department of Earth Sciences, University of Manitoba, Winnipeg, Manitoba, Canada R3T 2N2 and D. R. Bowes: Department of Geology, University of Glasgow, Glasgow G12 8QQ, Scotiand, U.K.

\section{Introduction}

The demonstration of the polymetamorphic nature of the early-middle Proterozoic Svecokarelides in eastern and central Finland (e.g. Campbell et al. 1979; Koistinen 1981; Treloar et al. 1981; Halden 1982 a; Park 1983 a, b) means that the concept of a general increase in metamorphic grade from $\mathrm{E}$ to $\mathrm{W}$ in central Finland
(Huhma 1975) needs amplification and integration with studies of mineral reactions and successive mineral growths throughout the region. This can be achieved by linking changes in $\mathrm{P}-\mathrm{T}$ conditions with changes in structural features from district to district and so establishing phase by phase regional variations through the polymetamorphic sequence on the basis of correlation of coevally developed minerals. Such infor- 
mation would then form a basis for assessing both regional and temporal variations in both heat flow and crustal depth of different parts of the orogen and thus be a powerful constraint on models erected to explain geotectonic development.

The mica schists in the vicinity of Savonranta, eastern Finland (Fig. 1), provide an excellent basis for providing information concerning the metamorphic history in one district as mineral growth sequences can be established in thin section and can be correlated with the macroscopic aspect of fold forms and their associated axial planar fabrics. In addition it has been found possible to derive quantitative estimates of pressure and temperature on the basis of the phase relationships expressed by various assemblages. This has been done using coexisting mineral pairs within suitable assemblages for which calibrated geothermometers and geobarometers exist.

The present study is not intended as a critique of the thermodynamic approach to determining pressures and temperatures as it is recognised that problems do exist, including the recognition of textural equilibrium or manifest as internal variations in mineral chemistry connected with zoning. Neither is it intended as a study whose results can be immediately extended to other areas in eastern and central Finland where the metamorphic rocks show a wide variety of mineral assemblages (e.g. Korsman 1977). Rather its aim is to provide information within the constraints of structural and sequential mineral development parameters permitting the elucidation of which phases were co-existing, and within the limits of a thermodynamic approach to provide quantitative comparisons of pressures and temperatures of metamorphism. Subsequently the results of this study can be used as part of an overall regional assessment of metamorphic history in this part of the Svecokarelides. However, this study and other studies of polymetamorphic mineral growth in the Svecokarelides (eg. Campbell et al. 1979; Park
$1983 \mathrm{~b})$ show that assessment of successively developed metamorphic conditions can only be meaningfully carried out in conjunction with detailed structural studies that elucidate an integrated structural, metamorphic and igneous history.

The present work is based on a field study of the area in Figure 1 during 1979, 1980, 1981 related to the structural, metamorphic and igneous history of the Savonranta district, the results of which are set out in Halden (1982 b). Evidence relating to the structural history and times of igneous emplacement are given in Halden (1982 a). Assessment of metamorphic conditions involved the collection of 300 specimens, most oriented, and the particular detailed study of 60 thin sections, selected from the collected suite as being most relevant and amenable to the style of approach; they provided the critical evidence for microfabric and microprobe studies. Grid references of the samples used in the microprobe study are given in the text and in the explanation of Table 1.

\section{Geological setting}

The mica schists of the Savonranta district (Fig. 1) form part of the Kalevian schists in the nomenclature of Nykänen (1975) and, on the basis of regional structural relationships, can be subdivided into two nappe units, the Outokum$\mathrm{pu}$ and the Savonranta nappes, the latter being uppermost (Koistinen 1981; Halden 1982 b; Park and Bowes 1983, fig. 18). They show the effects of a polydeformational and polymetamorphic history developed in conjunction with the repeated injection of quartzofeldspathic and granitic neosome material (Halden 1982 a). Individual features of the deformational sequence displayed in the mica schist palaeosome include two early phases of isoclinal fold development $\left(F_{1}\right.$ and $F_{2}$ ), followed by a phase of wrench fault movement associated with the development of small asymmetrical folds $\left(\mathrm{F}_{2 \mathrm{C}}\right)$. Later 
Fig. 1. Geological map of the Savonranta district showing the distribution of the main granitic masses and quartzofeldspathic neosomes in the palaeosome mica schist in relation to the major wrench fault zone (after Halden 1982 a, fig. 2). Also shown is the distribution of aluminosilicate polymorphs, garnet and cordierite (the latter indicates the position of the layered schist); data from Nykänen (1975) and Koistinen (1981) included; comp. foln. refers to a composite foliation which is the product of superimposing $\mathrm{S}_{2}$ on $\mathrm{S}_{1}$. Inset map gives the location of other metamorphic studies referred to in the text

in relation to major rock units.

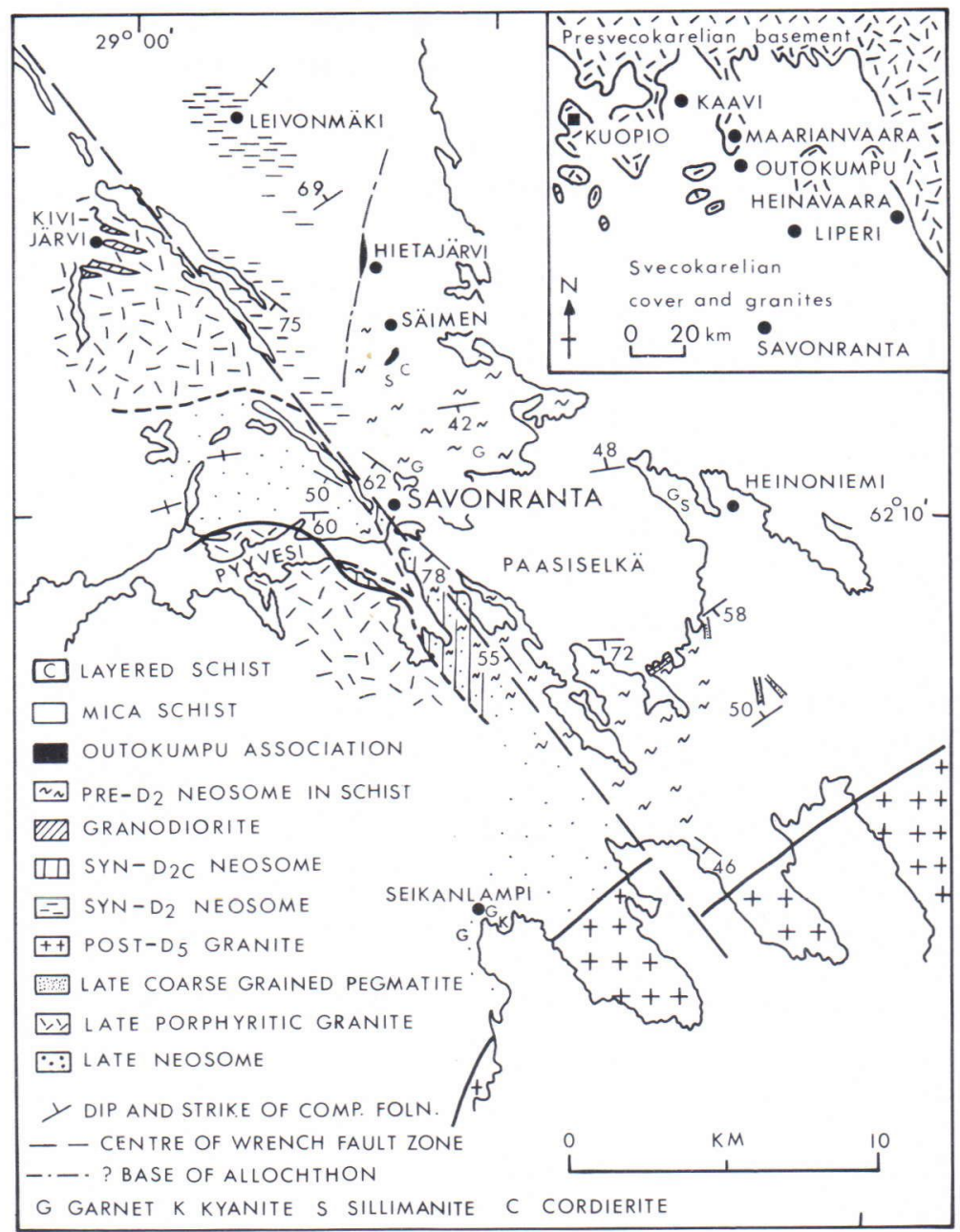

open folds with orthogonally disposed axial planes have been successively superimposed on this sequence and are referred to as $F_{3}$ and $\mathrm{F}_{\text {LATE }}$. For ease of discussion and integration of structural information with metamorphic events, deformational events associated with the production of the aforementioned folds will be referred to as $D_{1}, D_{2} \ldots$. This nomenclature follows that established for the Liperi and the Outokumpu districts (Fig. 1; Bowes 1976; Koistinen 1981), and used by Halden (1982 a) in describing the inter-relationship between folds $\left(\begin{array}{lll}\mathrm{F}_{1} & \ldots & \mathrm{F}_{\text {LATE }}\end{array}\right)$, and their associated axial planar fabrics $\left(\mathrm{S}_{1} \ldots \mathrm{S}_{\mathrm{LATE}}\right)$ developed in the mica schists in the vicinity of Savonranta. Pre $-D_{1}$ refers to a deformational phase that preceded the $\mathrm{D}_{1}$ deformational phase; this includes major thrust movements that resulted in the tectonic interdigitation of rocks from different crustal levels and different crustal segments (c.f. Koistinen 1981; Park and Bowes 1983).

A NW-SE-trending ductile shear zone along which there has been dextral displacement bisects the Savonranta district (Gáal 1972; Halden 1982 a). To the SW of this zone, areas of 
dilatency have acted as the sites of emplacement for a porphyritic granite, dated at c. $1780 \mathrm{~m}$.y. (Rb-Sr whole-rock; Halden 1982 a), which represents both the last phase and greatest volume of neosome material introduced into this crustal segment. Further information relating to the nature and distribution of structural elements and igneous masses in the Savonranta district is given in Halden (1982 a) and an in- terpretation of the regional structure north of the ductile shear zone is given by Park and Bowes (1983, pp. 116-117 and fig. 18). These authors provide evidence of three deformational phases characterised by extensive thrusting that predate the initiation of the ductile shear zone. They favour an interpretation of the Savonranta nappe which involves $D_{1}$ thrusting that led to the repetition of a pre- $\mathrm{D}_{1}$ tectonic stack.

Table 1. Chemical compositions of layered schist and mica schist.

\begin{tabular}{|c|c|c|c|c|c|c|c|}
\hline \multirow[b]{2}{*}{ Sample } & \multicolumn{3}{|c|}{ Layered schist } & \multicolumn{4}{|c|}{ Mica schist } \\
\hline & 1 & 2 & 4 & 5 & 8 & 9 & 10 \\
\hline $\mathrm{SiO}_{2}$ & 58.50 & 59.36 & 60.42 & 56.34 & 63.14 & 57.83 & 70.65 \\
\hline $\mathrm{TiO}_{2}$ & 0.88 & 0.78 & 0.64 & 0.86 & 0.79 & 0.84 & 0.62 \\
\hline $\mathrm{Al}_{2} \mathrm{O}_{3}$ & 17.88 & 16.58 & 17.66 & 17.52 & 14.86 & 16.41 & 11.67 \\
\hline $\mathrm{Fe}_{2} \mathrm{O}_{3}$ & $9.31^{*}$ & $9.11^{*}$ & $9.15^{*}$ & 1.66 & 1.83 & 2.29 & 1.55 \\
\hline $\mathrm{FeO}$ & - & - & - & 7.25 & 5.30 & 6.89 & 4.15 \\
\hline $\mathrm{MnO}$ & 0.10 & 0.10 & 0.10 & 0.07 & 0.06 & 0.06 & 0.06 \\
\hline $\mathrm{MgO}$ & 4.65 & 3.61 & 4.39 & 4.22 & 3.04 & 3.94 & 2.41 \\
\hline $\mathrm{CaO}$ & 1.53 & 1.94 & 1.25 & 3.32 & 1.75 & 1.47 & 1.90 \\
\hline $\mathrm{Na}_{2} \mathrm{O}$ & 1.75 & 2.06 & 1.60 & 4.61 & 3.09 & 2.89 & 4.69 \\
\hline $\mathrm{K}_{2} \mathrm{O}$ & 3.29 & 3.02 & 3.38 & 3.17 & 3.04 & 3.64 & 2.13 \\
\hline $\mathrm{P}_{2} \mathrm{O}_{5}$ & 0.12 & 0.14 & 0.09 & 0.11 & 0.15 & 0.15 & 0.13 \\
\hline$\underline{\mathrm{H}_{2} \mathrm{O}+}$ & - & - & - & 1.78 & 1.95 & 2.25 & 1.28 \\
\hline Total & 98.01 & 96.70 & 98.68 & 100.91 & 99.00 & 98.66 & 101.24 \\
\hline $\mathrm{La}$ & 19 & 20 & 17 & 23 & 20 & 18 & 16 \\
\hline $\mathrm{Cr}$ & 164 & 160 & 152 & 156 & 337 & 154 & 100 \\
\hline Co & 29 & 29 & 26 & 27 & 32 & 27 & - \\
\hline $\mathrm{Ni}$ & 87 & 73 & 75 & 60 & 155 & 60 & 27 \\
\hline $\mathrm{Zr}$ & 139 & 139 & 138 & 133 & 98 & 159 & 193 \\
\hline $\mathrm{Nb}$ & - & - & - & 14 & 11 & 14 & 12 \\
\hline $\mathrm{Cu}$ & 74 & 79 & 69 & - & 193 & 73 & 64 \\
\hline $\mathrm{Ga}$ & 25 & 20 & 27 & 20 & 12 & 30 & 15 \\
\hline $\mathrm{Zn}$ & 144 & 130 & 141 & 114 & 68 & 125 & 64 \\
\hline $\mathrm{Sr}$ & 140 & 173 & 108 & 415 & 80 & 117 & 337 \\
\hline $\mathrm{Y}$ & 24 & 24 & 25 & 22 & 17 & 23 & 17 \\
\hline $\mathrm{Rb}$ & 143 & 137 & 151 & 156 & $12 \mathrm{i}$ & 158 & 85 \\
\hline $\mathrm{Pb}$ & 19 & 22 & 12 & 35 & - & 30 & 18 \\
\hline Th & 10 & 11 & 12 & 22 & 12 & 12 & - \\
\hline $\mathrm{Ce}$ & 49 & 58 & 55 & 51 & 41 & 28 & 43 \\
\hline $\mathrm{Ba}$ & 557 & 131 & 506 & 381 & 495 & 811 & 559 \\
\hline
\end{tabular}

For layered schist samples, grid reference (from 1 : 50,000 topographic map) is 6904.65613 .35 and coexisting aluminosilicate is sillimanite.

For mica schist samples, grid references are $5-6907.60614 .30,8-6901.30627 .35,9-6906.55613 .35,10-6909.10$ 608.85 .

Major and trace elements were analysed by X-ray fluorescence on fused beads and pressed powder pellets, respectively, except for $\mathrm{FeO}$ and $\mathrm{H}_{2} \mathrm{O}+$ which were determined by volumetric and gravimetric methods, respectively.

* Total $\mathrm{Fe}$ as $\mathrm{Fe}_{2} \mathrm{O}_{3}$

Grid references and coexisting aluminosilicate for other mica schist samples referred to in the text are $6-6901.10613 .30$ (sillimanite), 7 - 6878.50621 .45 (kyanite), $11-6878.95621 .25$ (sillimanite). 


\section{Rock types}

On the basis of macroscopic field aspect and mineralogy, a distinction is drawn between the predominant mica schist, with its calc-silicate variants, and a lithology referred to as 'layered schist' that was observed at one locality $\mathrm{N}$ of Savonranta (G.R. 6904.65 613.35). The mutual relationships between the layered schist and the predominant mica schist are not clear, even though outcrops of the two rock types are found separated by only a few metres. There is, however, a possibility that the layered schist represents a tectonically interdigitated slice from a deeper crustal level (Halden 1982 b); this interpretation is consistent with the evidence of major thrusting in the region (Park and Bowes 1983). Chemical data for the varieties of schist are given in Table 1.

\section{Mica schist}

The thickness of individual layers varies from about $2 \mathrm{~cm}$ to some metres, the layering being the results of original sedimentary differences and tectonic modification. Quartz (10-50 \%), biotite $(20-30 \%)$ and plagioclase $\left(\mathrm{An}_{25-30}\right.$, $10-30 \%$ ) predominate with different layers containing varying proportions of these minerals. On the criteria of Leake (1970) most of the schists can be classified as semipelitic, although psammitic varieties do occur; the An content of the plagioclase is consistent with such an affinity (c.f. Miyashiro 1973). Locally there are porphyroblastic growths of fibrolitic sillimanite, garnet, kyanite and muscovite whose relationships to metamorphic and deformational events are discussed later (c.f. Fig. $3 \mathrm{c}, \mathrm{d}, \mathrm{f}$ ). There are also small isolated intercalations with minor proportions of epidote: for convenience of description they are referred to as calc-silicate schist.

\section{Layered schist}

Light-coloured, quartz-rich bands approximately $7 \mathrm{~cm}$ thick with a distinct joint pattern developed at right angles to the margins of the unit alternate with dark-coloured mica-rich bands. Within the outcrop these bands do not vary in thickness and their contiguous nature may indicate that during deformation the layered schist behaved as a coherent, competent tectonic unit, relative to the surrounding mica schist. Overall the rock is coarse grained; the quartz-rich layers have an equigranular texture with weak schistosity, and the mica-rich layers a well-developed schistose texture. The constituent minerals in both types of layer are quartz, biotite, garnet, plagioclase $\left(\mathrm{An}_{29-32}\right)$, cordierite and sillimanite; pinnite forms along irregular fractures as an alteration product of cordierite (c.f. Fig. 3 a, b).

\section{Relationship between mineral reactions and the sequential development of mineral assemblages}

Considering both types of schist together the mineral assemblages observed are:

(1) quartz + biotite + plagioclase

(2) quartz + biotite + plagioclase + chlorite

(3) quartz + biotite + plagioclase + garnet

(4) quartz + biotite + plagioclase + garnet + sillimanite

(5) quartz + biotite + plagioclase + sillimanite

(6) quartz + biotite + plagioclase + garnet + potassium feldspar + kyanite + muscovite + chlorite $(+$ ?graphite), and

(7) quartz + biotite + plagioclase + sillimanite + cordierite + garnet $(+$ minor andalusite $)$.

The significant proportions of sillimanite in the presence of excess quartz mean that the mineral asseblages can be described in the ACF and AKF fields defined by Eskola (1915) in a manner similar to that employed by Turner (1981) for the amphibolite facies (sillimanite zone) in the case of the mica schists (Fig. 2 b, c) and for the granulite facies in the case of the layered schist (Fig. 2 a); the latter is influenced by the presence of cordierite. 

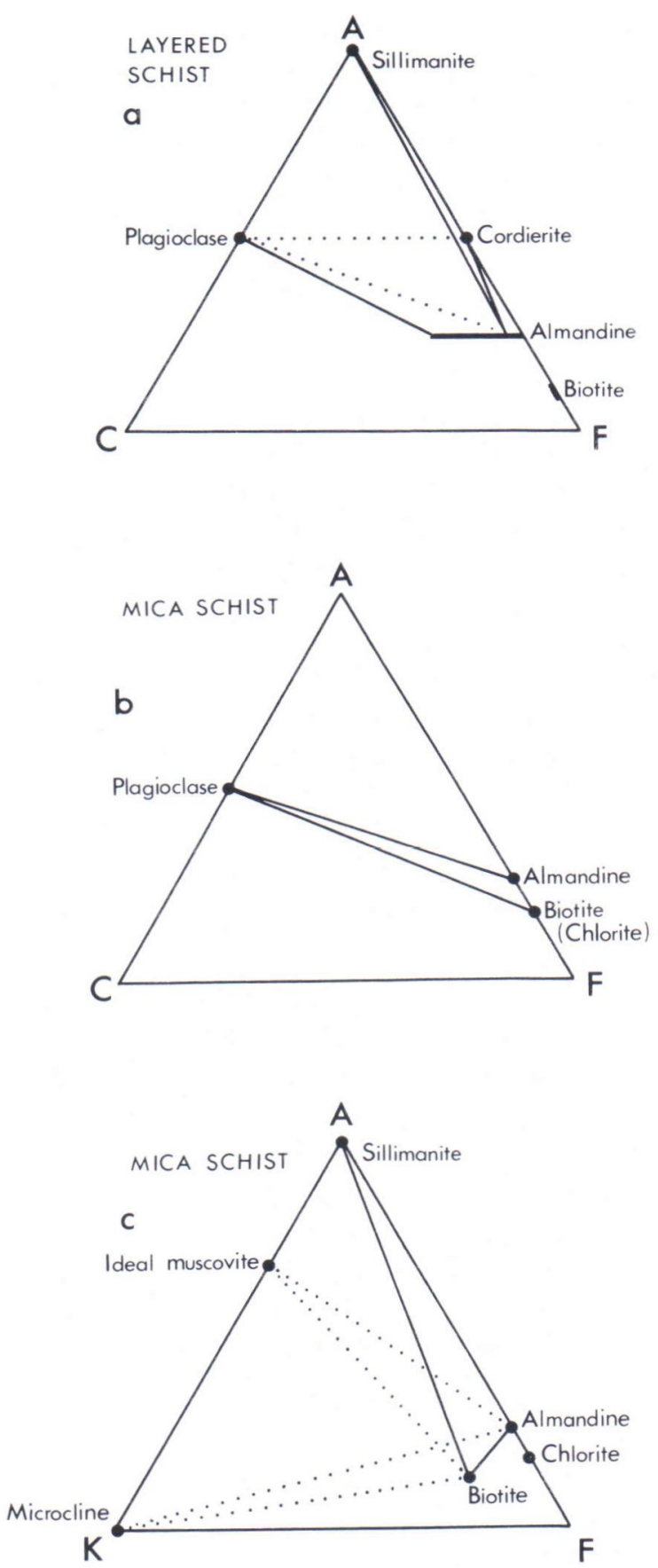

Fig. 2. (a) ACF diagram showing coexisting minerals at granulite facies that can account for the mineral assemblage in the layered schist. (b) \& (c) ACF and AKF diagrams showing coexisting minerals at amphibolite facies, sillimanite - muscovite zone, for the mineral assemblages in the mica schist.
The assemblages in the layered and mica schists have been assessed to be in textural equilibrium as long as there are clear indications of the sequence of mineral growths, and the criteria outlined by Vernon (1976) are not violated. A review of the minerals in equilibrium is critical to an assessment of the viability of geothermometers and geobarometers such as those calibrated by Ghent (1976), Thompson (1976), Ghent and Stout (1981), Newton and Haselton (1981) and Perchuk et al. (1981). On the basis of cross-cutting relationships (c.f. Fig. 3 ) it is clear that some minerals have a recurring paragenesis and that definite relationships do exist between certain minerals. The relationship between the various mineral growths with the schists and metamorphic and deformational events will be discussed later.

Mineral assemblage 7 is unique to the layered schist exhibiting a complex sequence of mineral growths manifest in the overprinting of cordierite by biotite and fibrolitic sillimanite (Fig. 3 a). This resultant assemblage is then overgrown by prismatic sillimanite (Fig. 3 a) and garnet porphyroblasts (Fig. $3 \mathrm{~b}$ ); biotite has also probably regrown during these phases of metamorphism. This mineral assemblage can be accounted for by the following reactions:

(a) cordierite $\rightleftharpoons$ almandine + sillimanite + quartz (Thompson 1976; Holdway and Lee 1977), and

(b) cordierite + orthoclase $\rightleftharpoons$ biotite + $\mathrm{Al}_{2} \mathrm{SiO}_{5}+$ quartz (Holdaway and Lee 1977).

The phase boundary for reaction (b) can intersect that between andalusite and sillimanite (Fig. 5; using the Holdaway (1971) triple point for the aluminosilicate polymorphs) and so could account for the small andalusite inclusion within the garnet in Figure $3 \mathrm{~b}$; the relationship between the garnet and sillimanite in the same sample could not be resolved. If the garnet was a consequence of reaction (a) then it would be necessary for reaction (a) to post-date reaction 

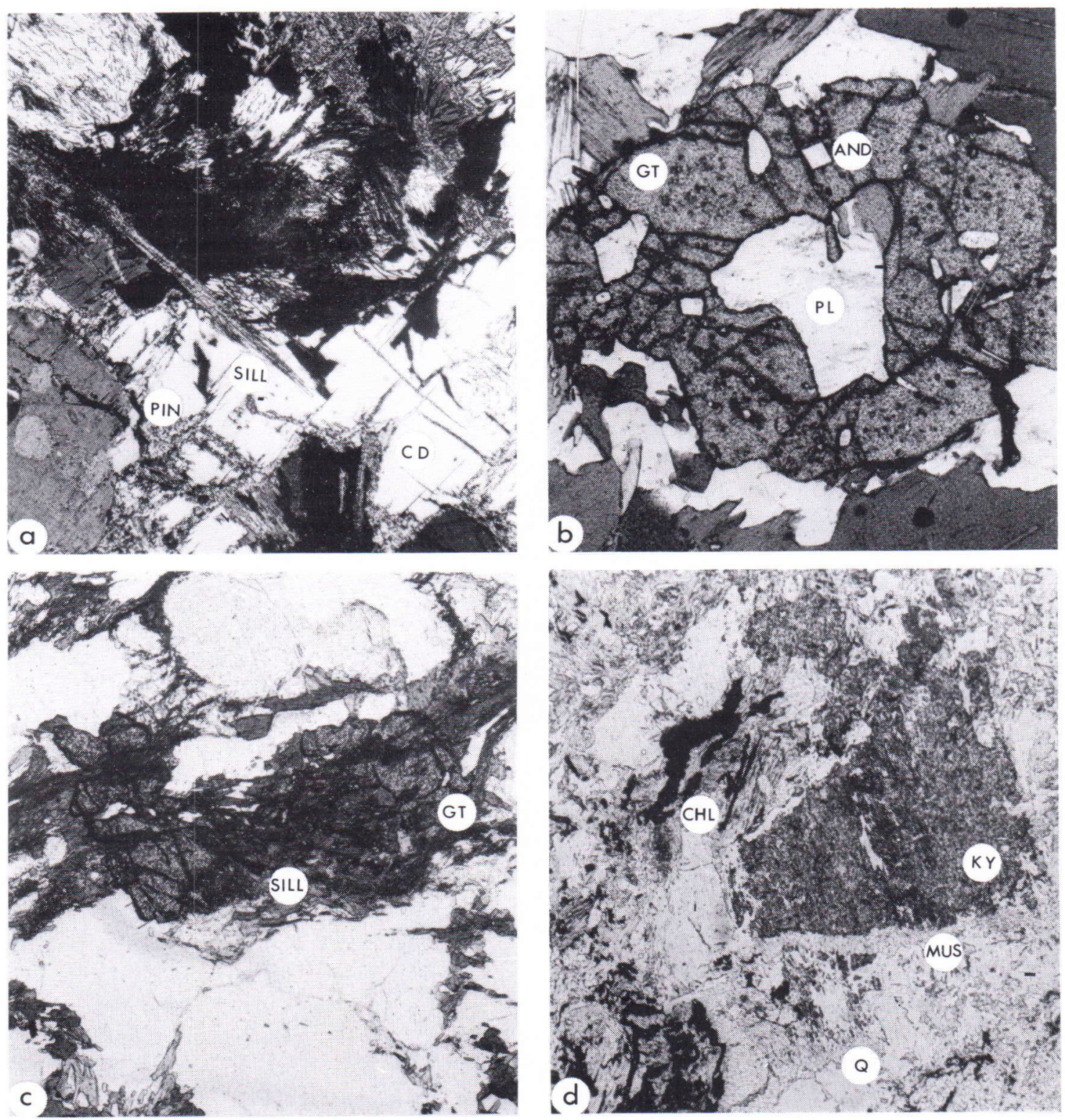

Fig. $3 \mathrm{a}-\mathrm{d}$ (Note the caption on the next page)

(b), with the absence of potassium feldspar suggesting that it had been consumed in reaction (b). As these reactions are largely pressure sensitive, the absence of hypersthene as the breakdown product of biotite constrains the upper limits at which reaction (a) could have taken place, and the lack of any evidence of partial melting constrains the upper limits of temperature for reaction (b).

The other mineral assemblages $(1-6)$ present in the mica schist make it necessary to account for the production of biotite, garnet, sillimanite and kyanite as the result of the following reactions: 

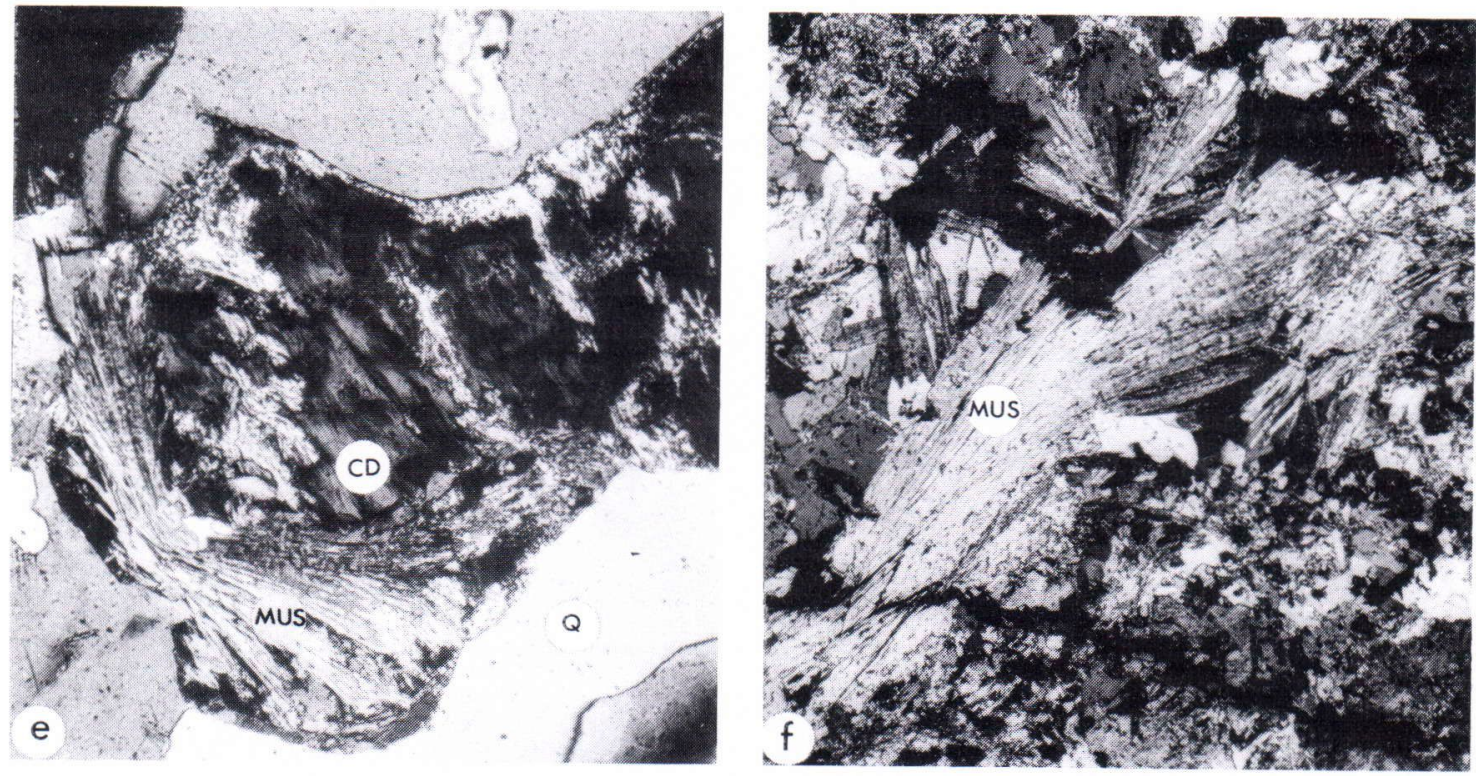

Fig. 3. Mineral relationships from layered and mica schists. (a) Layered schist with prismatic sillimanite growth (Sill) overgrowing fibrolitic sillimanite; both have overgrown cordierite $(\mathrm{Cd})$ : note alteration of cordierite to pinite (Pin) along fractures; $\times 35$, PPL, sample 2. (b) Layered schist with garnet porphyroblast (Gt); inclusions include euhedral andalusite (And) and plagioclase $(\mathrm{Pl}) ; \times 30$, PPL, sample 3. (c) Mica schist with fibrolitic sillimanite (Sill) that defines $\mathrm{S}_{2}$ overgrowing degraded porphyroblastic garnet $(\mathrm{Gt}) ; \times 35$, PPL, sample 11 . (d) Mica schist with kyanite crystal (Ky) mantled by muscovite (Mus); this relationship is accounted for by reaction (e) (see text); chlorite (Chl) probably formed from the breakdown of biotite; $\times 35, \mathrm{PPL}$, sample 7 . (e) Layered schist with muscovite asterisms (Mus) overgrowing cordierite (Cd); $\times 75, \mathrm{XN}$, sample 3. (f) Mica schist with muscovite asterism (Mus); $\times 30, \mathrm{XN}$, sample 7.

(c) chlorite + quartz $\rightleftharpoons$ garnet $+\mathrm{H}_{2} \mathrm{O}$ (Miyashiro 1968), and

(d) chlorite + muscovite + quartz $\rightleftharpoons \mathrm{Al}_{2} \mathrm{SiO}_{5}$ + biotite $+\mathrm{H}_{2} \mathrm{O}$ (Miyashiro 1973).

In both cases, as chlorite and muscovite are generally associated with retrograde paragenesis (see later), these reactions proceeding from left to right during prograde metamorphism would necessitate the total consumption of both muscovite and chlorite.

It is possible to establish time relations between certain minerals in the mica schists. In some cases early garnet porphyroblasts have been overgrown by fibrolitic sillimanite (Fig. 3 c) which parallels $S_{2}$. Other relationships show that fibrolitic sillimanite has been deformed around garnet porphyroblasts, which may indicate contemporaneous growth, whereas still other garnet growths exhibit corroded forms. This information suggests that garnets have grown in response to, and have been affected by, more than one metamorphic event. However, in most cases of porphyroblastic garnet development, in both the mica and layered schists, it has not been found possible to resolve their growth in relation to linear or planar structural features as was done by MacQueen and Powell (1977) and Campbell et al. (1979). This is due mainly to the small size of most of the garnets and to the random orientation of inclusions. Nevertheless the zoned nature of the garnets, shown by microprobe analysis, indicates that there were variations in chemistry during their growth.

The production of kyanite is most likely to be 
a consequence of reaction (d), perhaps having proceeded first through the andalusite stability field. The kyanite crystal in Figure $3 \mathrm{~d}$ appears to be an early mineral growth on the basis of its corroded form and the fact that it is mantled by muscovite, considered to be a late mineral growth (see later). Had the kyanite been the product of reaction between muscovite and quartz, or of muscovite breakdown, it would have necessitated pressure in the order of $12 \mathrm{~kb}$ to proceed, but there is no corroborative evidence of this (c.f. Fig. 5).

Late mineral reactions within the mica schist include the breakdown of biotite to form chlorite, most likely under oxidising conditions; this feature can be directly related to the $\mathrm{S}_{\mathrm{L}}$ fracture cleavage in Figure 4. Chlorite is also produced from the breakdown of garnet, probably indicating a reversal of reaction (c). Although there is no direct evidence, it is likely that this is also associated with $\mathrm{D}_{\text {LATE}}$. Another late mineral reaction is responsible for the production of muscovite. In Figure $3 \mathrm{~d}$ there is direct evidence that the muscovite has come from the breakdown of kyanite because of its mantling relationship possibly due to the following reaction:

(e) orthoclase $+\mathrm{Al}_{2} \mathrm{SiO}_{5}+\mathrm{H}_{2} \mathrm{O} \rightleftharpoons$ muscovite + quartz (Evans 1965).

Orthoclase, although present as a primary phase in the mica schist (assemblage 6; p. 7), is most definitely not a major component. For reaction (e) to proceed to the right and produce muscovite and quartz it would still be difficult to determine the absolute quantities of the minerals required. To balance reaction (e), in the presence of excess water, 2 moles of orthoclase react with 1 mole of kyanite to give 1 mole each of muscovite and quartz. A possible deficiency of orthoclase may be met by its introduction, or at least the introduction of a potassium-rich fluid, for the reaction to proceed. This appears likely, as mobility of an orthoclase-bearing fluid is a feature associated with the emplacement of the porphyritic granite in the SW of the Savonranta district, a granitoid with a noticeable preponderance of potassium feldspar phenocrysts (c.f. Halden 1982 a, b).

A regional heating event associated with granite emplacement could account for the muscovite asterisms (a static metamorphic growth) observed in the sample containing the kyanite crystals (Fig. 3 f). Reaction (e) could also be used to account for muscovite asterisms in the layered schist but again would require the introduction of orthoclase. If, however, as seems more likely, the muscovite was caused by the breakdown of silliminate in the layered schists, which itself was produced by the breakdown of cordierite, the following reaction may have taken place:

(f) biotite + sillimanite + quartz $\rightleftharpoons$ muscovite + cordierite (Seifert 1970).

This could explain the intimate association of the muscovite with cordierite (Fig. 3 e) and may indicate a more restricted paragenesis in terms of $\mathrm{P}$ and $\mathrm{T}$ (see later). In these circumstances another growth of cordierite would also result; no evidence of this was found but the possibility cannot be discounted.

\section{Relationship of metamorphic events to the sequential mineral development and deformational sequence}

The recurring paragenesis of some minerals necessitates the elucidation of a sequence of mineral growths that can be related to a sequence of metamorphic reactions depending upon the mineralogy and chemistry of the host rock. A sequence of metamorphic reactions can be established using the textural relationships between the minerals on the basis of (1) crosscutting relationships, (2) overgrowth relationships and (3) essentially subjective observations on whether mineral boundaries are sharp, suggesting equilibrium or prograde metamorphism, or appear corroded, suggesting retrograde metamorphism. 


\section{In layered schist}

Overgrowth and cross-cutting relationships allow four metamorphic events to be established.

1. $M_{\text {EARLY }}\left(M_{E}\right)$ which accounts for the cordierite growth; a cordierite-biotite-plagioclase assemblage would be consistent with granulite facies metamorphism.

2. The $\mathbf{M}_{\mathrm{E}}$ mineral assemblage is overgrown by a fibrolitic sillimanite growth (Fig. 3 a) ascribed to reaction (b) and designated as a consequence of the $\mathbf{M}_{1}$ metamorphic event.

3. The $\mathbf{M}_{1}$ fibrolitic sillimanite growth is overgrown by prismatic sillimanite (Fig. $3 \mathrm{a}$. This second growth is the product of reaction (a) and is designated as having occurred in association with the $\mathrm{M}_{2}$ metamorphic event. The garnet growth in this rock is also the product of reaction (a) during the $\mathbf{M}_{2}$ event; noticeably some garnet porphyroblasts have inclusions of andalusite (Fig. $3 \mathrm{~b}$ ), which are a possible product of the preceding reaction (b) and so should be associted with $\mathbf{M}_{1}$. (It should be noted that both $\mathrm{M}_{1}$ and $\mathrm{M}_{2}$ are associated with oriented mineral growths, expressed by both biotite and silliminate in the mica and layered schists, suggesting that they were dynamic phases of metamorphism.) The conditions of metamorphism associated with $\mathbf{M}_{2}$ occur very close to the minimum melting conditions of $\mathrm{Ab}-\mathrm{Or}-\mathrm{Qtz}$ under wet conditions, the coexisting aluminosilicate polymorph being sillimanite (Fig. 5).

4. Muscovite asterisms are observed with overgrowth relationships on some cordierite crystals. The radial disposition of the muscovite blades (Fig. 3 e) suggests static growth that is unlikely to be associated with $\mathbf{M}_{1}$ or $\mathbf{M}_{2}$. The absence of any evidence of partial melting associated with the muscovite growth indicates metamorphic conditions below those for $\mathbf{M}_{2}$. These can be constrained to be between curves $\mathrm{E}$ and $\mathrm{D}$ on Figure 5 and so represent a distinct metamorphic event referred to as $\mathrm{M}_{\mathrm{LATE}}$ ' $\left(\mathrm{M}_{\mathrm{L}}{ }^{\prime}\right)$.

\section{In mica schist}

Metamorphic events affecting the mica schist follow a similar general pattern to those in the layered schist, with relatively early sillimanite and garnet growths. However, there is no evidence of anything equivalent to the mineral phases indicative of the $\mathrm{M}_{\mathrm{E}}$ event. Figure $3 \mathrm{c}$, in which sillimanite is seen overgrowing a garnet porphyroblast, indicates two metamorphic events at middle amphibolite facies affecting the mica schist. In terms of grade these could be equivalent to $M_{1}$ and $M_{2}$ in the layered schist, the garnet growth to $\mathrm{M}_{1}$ and the sillimanite growth to $\mathrm{M}_{2}$. The oriented sillimanite growth in Figure $3 \mathrm{c}$ defines $\mathrm{S}_{2}$. This suggests that the $\mathrm{D}_{2}$ deformational phase in this rock can be correlated with the $\mathrm{M}_{2}$ metamorphic event in the layered schist during which there was also dynamic mineral growth. The sillimanite grade of metamorphism for $\mathrm{M}_{2}$ in the mica schist is corroborated in some lithologies, by the nature of rotated silliminate porphyroblasts, which show evidence of initial development as fibrolite concordant with $\mathrm{S}_{1}$ and further recrystallisation and rotation during $\mathrm{D}_{2}$ (c.f. Halden 1982 a, fig. $5 \mathrm{~b}$ ). This corresponds to the overgrowing of $M_{1}$ fibrolitic sillimanite by $M_{2}$ prismatic sillimanite in the layered schists. The presence of early-grown garnet in the mica schist (c.f. Fig. $3 \mathrm{c}$ ) may also account for some corroded garnet porphyroblasts that have subsequently undergone retrogressive metamorphism. However, it must not be confused with the garnet growth in the layered schist, which is a consequence of reaction (a) and therefore associated with $\mathrm{M}_{2}$. In the mica schist the garnets are more likely to be a consequence of reaction (c) during $M_{1}$.

As in the layered schist, static muscovite asterisms in the mica schist (Fig. $3 \mathrm{f}$ ) point to a metamorphic event distinct from $M_{1}$ and $M_{2}$. The stability of muscovite in relation to the assemblages and reactions already described restricts this growth to the field delineated for $\mathrm{M}_{\mathrm{L}}$ ' (Fig. 5). The growths in both the layered and mica schists are probably contemporaneous 


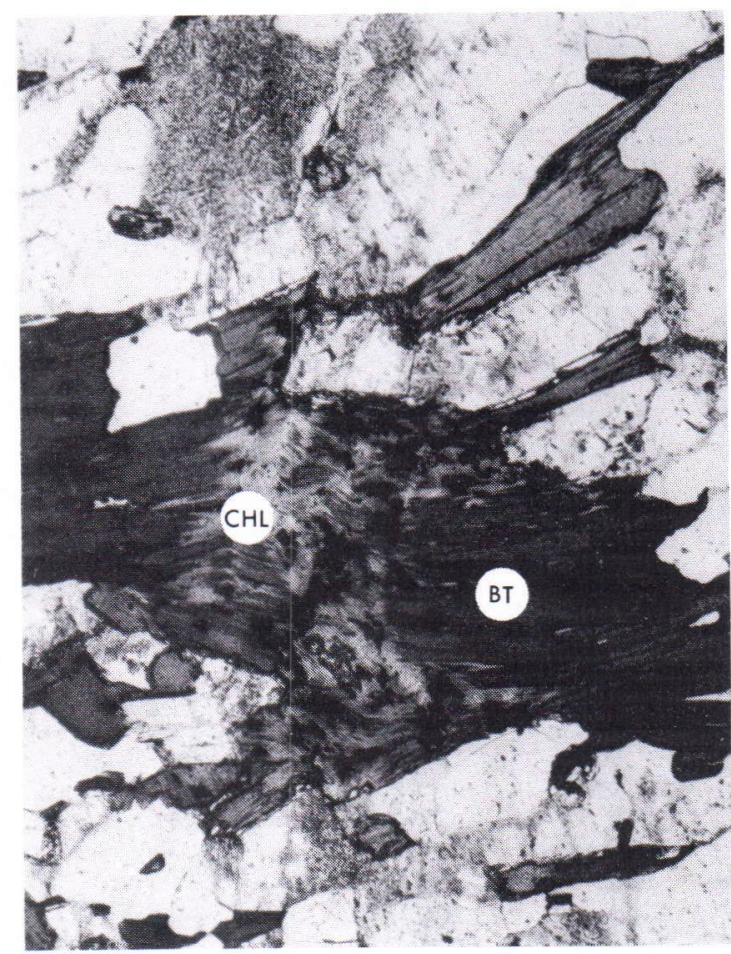

Fig. 4. Oriented biotite flakes (Bt) in $\mathrm{S}_{2}$ disrupted in the $\mathrm{S}_{\mathrm{L}}$ fracture cleavage associated with chlorite (Chl) formation.

1850 m.y. post- $\mathrm{D}_{3}-$ pre- $\mathrm{D}_{4}$ pegmatites (van Breemen and Bowes 1977; age recalculated using constant of Steiger and Jäger 1977) $\mathrm{M}_{\mathrm{L}}$ ' post-dates $\mathrm{M}_{3}$.

The following correlation between metamorphic events and phases of deformation and igneous emplacement in the Savonranta district best fits the available evidence (c.f. Halden 1982 a):

$$
\begin{array}{lll}
M_{E} & \ldots \ldots & ? \\
- & \ldots \ldots & \text { pre- } D_{1} \text { (nappe formation) } \\
\mathrm{M}_{1} & \ldots \ldots & \mathrm{D}_{1} \\
\mathrm{M}_{2} & \ldots \ldots & \mathrm{D}_{2} \\
- & \ldots \ldots & \mathrm{D}_{2 C} \text { (wrench fault movement) } \\
\mathrm{M}_{3} & \ldots \ldots & \mathrm{D}_{3}-\mathrm{D}_{\mathrm{L}} \\
\mathrm{M}_{\mathrm{L}} & \ldots \ldots & \text { porphyritic granite emplacement. }
\end{array}
$$

Figure 6 summarises the relationship between mineral growths and metamorphic events that have produced schistosity (MS) and those producing porphyroblasts (MP), excluding the mineral growth related to $\mathrm{M}_{\mathrm{E}}$.

\section{Conditions of metamorphism}

and associated with a heating event connected with the emplacement of the porphyritic granite.

A feature confined to the mica schist is the development, within a late fracture cleavage $\left(\mathrm{S}_{\mathrm{L}}\right)$, of chlorite, retrogressive from biotite (Fig. 4). Because of their $\mathrm{P}-\mathrm{T}$ ranges, none of the metamorphic events previously referred to could account for this chlorite growth, whose development represents a distinct phase designated $\mathrm{M}_{3}$. The inter-relationship between $\mathrm{M}_{3}$ and $\mathrm{M}_{\mathrm{L}}{ }^{\prime}$ is not clear in the mica schist. However, as the chlorite develops within fracture cleavages affecting biotite flakes in an $\mathrm{S}_{2}$ orientation, $\mathbf{M}_{3}$ post-dates $\mathbf{M}_{2}$. The porphyritic granite whose emplacement is associated with $\mathbf{M}_{\mathbf{L}}{ }^{\prime}$ is dated at c. 1780 m.y. (Halden, 1982 a), and if $\mathrm{S}_{\mathrm{L}}$ in the Savonranta district can be correlated with $\mathrm{S}_{4}$ regionally (c.f. Bowes, 1976) then on the basis of a regional correlation involving $c$.

Observations on metamorphic conditions within the schists are dominated by the presence of sillimanite, and many reactions involving mafic phases have taken place within the sillimanite stability field. The triple point of the aluminosilicate polymorphs used in Figure 5 is that calibrated by Holdaway (1971) at $501^{\circ} \mathrm{C}$ and $3.76 \mathrm{~kb}$. The other triple point commonly used in the literature is that of Richardson et al. (1969) at c. $630^{\circ} \mathrm{C}$ and $5.5 \mathrm{~kb}$, but this greatly reduces the size of the silliminate stability field below the minimum melting curve for $\mathrm{Ab}-$ Or-Qtz (c.f. Thompson 1976). The latter would necessitate, with such abundant sillimanite present in the schists of the Savonranta district, that the metamorphic events affecting the schists were restricted to a narrow range of temperature and pressure, or that there had been abundant partial melting of the schist for 


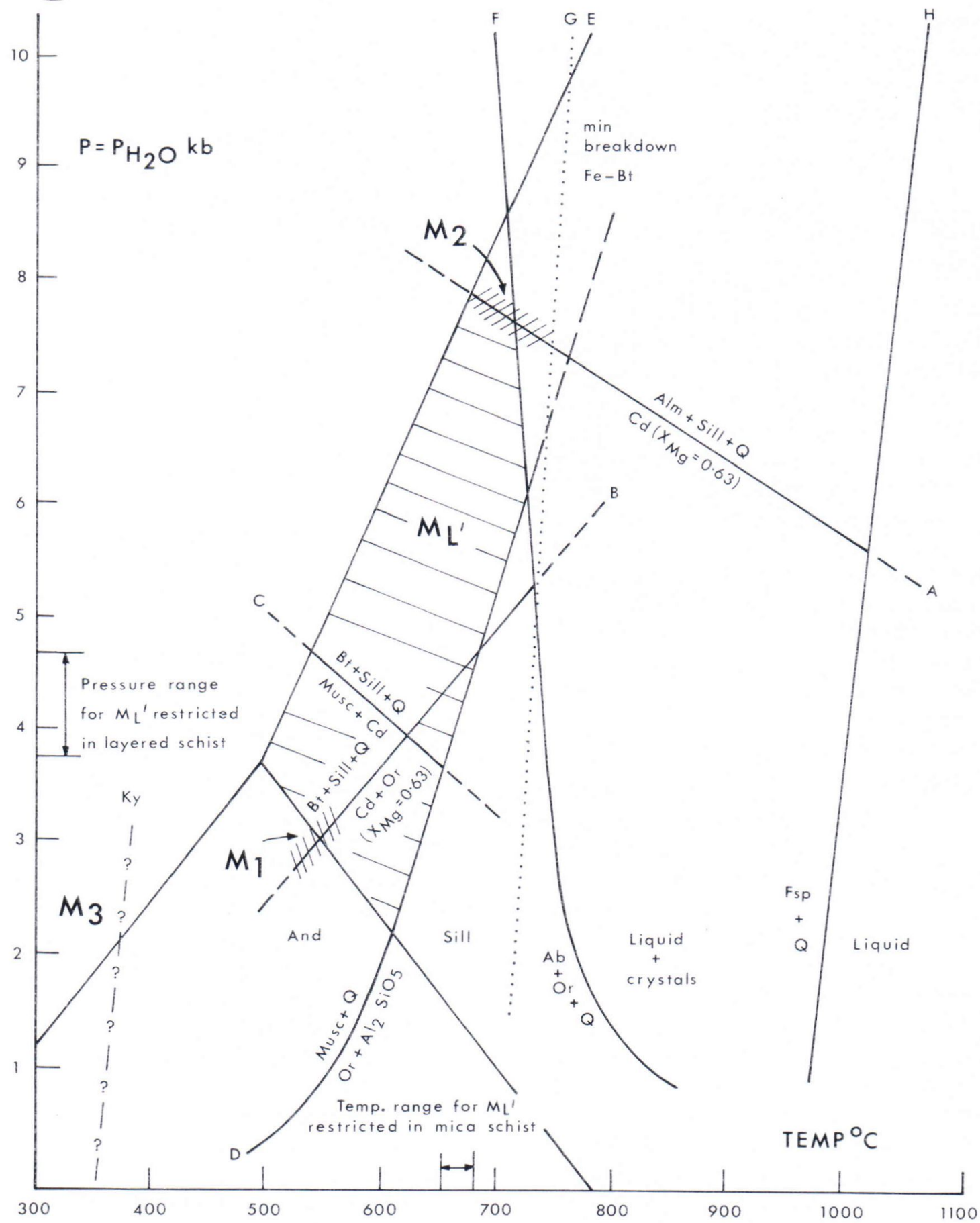

Fig. 5. Petrogenetic grid showing metamorphic reactions delimiting the probable range of metamorphic conditions that existed during $\mathrm{M}_{1}, \mathrm{M}_{2}, \mathrm{M}_{3}$ and $\mathrm{M}_{\mathrm{L}}$ '; curves $\mathrm{A}$ and $\mathrm{C}$ define reactions unique to the layered schists; $\mathrm{A}$ Thompson (1976), B Holdaway and Lee (1977), C Seifert (1970), D Evans (1965), E Holdaway (1971), F and H Wyllie et al. (1976), G Miyashiro (1973); Ab albite, Alm almandine, And andalusite, Bt biotite, Cd cordierite, Fsp feldspar, Ky kyanite, Musc muscovite, Or orthoclase, Q quartz, Sill sillimanite. 
which there is no field evidence. To a certain extent, therefore, the choice of the Holdaway (1971) triple point is arbitrary and the boundaries shown cannot be considered so precise as to preclude the coexistence of apparently incompatible phases.

\section{Metamorphic conditions in $P-T$ space derived from the layered schist}

The garnet-sillimanite-biotite assemblage has been superimposed on a pre-existing assemblage that was most likely biotite, cordierite, plagioclase and quartz (c.f. Fig. 3 a). This latter assemblage might be construed as the product of a low P, high T metamorphic event (c.f. Turner 1981). However, although the presence of biotite negates the possibility that the assemblage (with its present mineralogy) represents a water-deficient restite from which a hydrous granitic melt had been removed (c.f. Harris 1977), it is not clear whether the assemblage is the retrogressive product of metamorphism that took place at granulite or pyroxene granulite facies. The low $\mathrm{P}-$ high $\mathrm{T}$ metamorphism obviously pre-dated $D_{1}$ as both the $F_{1}$ folds and the $S_{1}$ metamorphic differentiation fabric (c.f. Halden 1982 a), paralleled by the fibrolitic sillimanite, are superimposed on the pre-existing cordierite-bearing mineral assemblage.

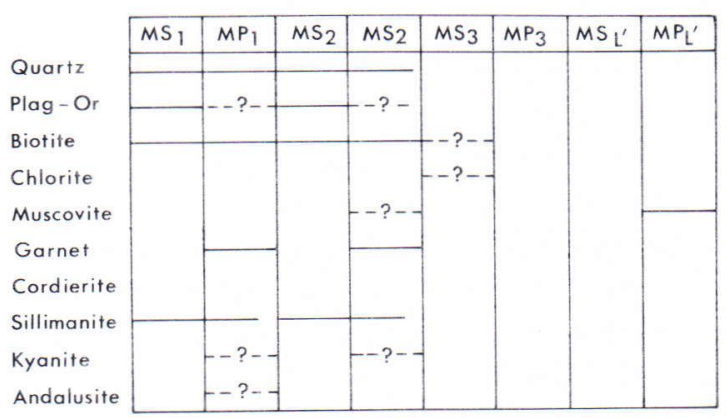

Fig. 6. Mineral growth sequence in the layered schist and mica schist excluding growths related to $\mathrm{M}_{\mathrm{E}}$; MS refers to oriented mineral growth defining a schistosity, and MP to porphyroblastic mineral development.
In the destruction of the cordierite-bearing assemblage, reaction (b) (for $\mathrm{X}_{\mathrm{Mg}}^{\mathrm{cd}}=0.63$; see Table 3) would proceed to give biotite, sillimanite and quartz (possibly with a small amount of andalusite) at $500^{\circ}-600^{\circ} \mathrm{C}$ at about $3 \mathrm{~kb}$ pressure; these are interpreted as representing the $\mathrm{P}-$ $T$ conditions of $M_{1}$ (Fig. 5). The $M_{1}$ mineral assemblage has been overgrown by the almandine, sillimanite and quartz produced from the further consumption of cordierite (reaction (a)) at about $700^{\circ} \mathrm{C}$ and $7-8 \mathrm{~kb}$ pressure; these are interpreted as representing the $\mathrm{P}-\mathrm{T}$ conditions of $M_{2}$ (Fig. 5). The second reaction is not associated with either partial melting or the breakdown of biotite, so with respect to temperature it is unlikely that these phase transitions have been crossed. These data indicate a decrease in the geothermal gradient in the Savonranta district between $\mathrm{M}_{1}$ and $\mathrm{M}_{2}$ from $c .55^{\circ} \mathrm{C} / \mathrm{km}$ to $c$. $30^{\circ} \mathrm{C} / \mathrm{km}$.

Late mineral reactions producing muscovite in the layered schist are either (1) the result of reaction (e), the transition being achieved between about $600^{\circ}$ and $700^{\circ} \mathrm{C}$ and between 2 and $6 \mathrm{~kb}\left(\mathrm{M}_{\mathrm{L}}{ }^{\prime} ;\right.$ Fig. 5), or (2) if the co-existing and breaking-down aluminosilicate was sillimanite, as seems likely, and this was a consequence of reaction (b), then it might restrict the muscovite paragenesis as a result of reaction (f) to between $500^{\circ}$ and $600^{\circ} \mathrm{C}$ at $3.7-4.7 \mathrm{~kb}$ (Fig. 5). These temperatures are consistent with what might be expected to be associated with the emplacement of the porphyritic granite. The paragenesis of the muscovite may be further restricted if considered in conjuction with evidence from the mica schist (see later).

\section{Metamorphic conditions in $P-T$ space derived from the mica schist}

Garnet, kyanite and sillimanite are three phases that occasionally provide an elaboration on the dominant quartz-plagioclase-biotite assemblage in the mica schist. The pre- $\mathrm{M}_{2}$ garnet growth (Fig. $3 \mathrm{c}$ ) probably represents meta- 
morphic conditions between $400^{\circ}$ and $600^{\circ} \mathrm{C}$ in excess of c. $3.5 \mathrm{~kb}$ for $\mathrm{M}_{1}$ (c.f. Turner 1968). This generally corresponding with the $500^{\circ}-$ $600^{\circ} \mathrm{C}$ and $3 \mathrm{~kb}$ conditions for $\mathrm{M}_{1}$ derived from the layered schist. The garnet growth is overgrown by a sillimanite growth parallel to $\mathrm{S}_{2}$, which might suggest increasing temperature during an $\mathrm{M}_{2}$ event, reflected again in the layered schist assemblage. Further evidence of a relatively early and relatively high $\mathrm{P}$ metamorphism is provided by the kyanite growth shown in Figure $3 \mathrm{~d}$, which in terms of time is only known to pre-date the late muscovite growth. It could, however, indicate conditions comparable with those associated with early garnet growth, suggesting temperatures of $400^{\circ}$ $-500^{\circ} \mathrm{C}$ at around $4 \mathrm{~kb}$. The $\mathrm{M}_{3}$ chlorite growth from the breakdown of biotite or garnet probably indicates metamorphic conditions during the event in the order of $2-3 \mathrm{~kb}$ at about $350^{\circ} \mathrm{C}$ (c.f. Turner 1968). The temperature and pressure of the $\mathrm{M}_{\mathrm{L}}$ ' development of muscovite correspond to those derived for this event in the layered schist.

If reaction (f) was responsible for the muscovite growth in the layered schist, and sillimanite was the degrading aluminosilicate, then the pressure range over which this reaction could be solely responsible for the production of muscovite is $3.7-4.7 \mathrm{~kb}$ (Fig. 5). This range, when projected onto the phase transition between muscovite and quartz going to $\mathrm{Al}_{2} \mathrm{SiO}_{5}$ and orthoclase, defines a temperature range over which a reversal of reaction (e) could take place in the mica schist $\left(\mathrm{M}_{\mathrm{L}}{ }^{\prime} ; 655^{\circ}-685^{\circ} \mathrm{C}\right)$ to produce muscovite. Inferring also from the corroded form of kyanite (Fig. 3 d) that this miner$\mathrm{al}$ is in disequilibrium, then in reacting, it must be doing so from well out of its stability field; this suggests a considerable increase in temperature during $\mathrm{M}_{\mathrm{L}}{ }^{\prime}$. Ideally, $655^{\circ} \mathrm{C}$ and $3.7 \mathrm{~kb}$ would be the temperature and pressure conditions at which $\mathrm{M}_{\mathrm{L}}$ ' would satisfy constraints defined by both mica and layered schist mineral assemblages and the contemporaneous produc- tion of muscovite in both. This assumes that the present erosion surface from which the samples were taken was overall at a similar crustal level during $\mathrm{M}_{\mathrm{L}}{ }^{\prime}$. On this assumption, and on the various lines of evidence that indicate $\mathrm{M}_{\mathrm{L}}{ }^{\prime}$ is related to the emplacement of the porphyritic granite, this approach allows both vertical and horizontal geothermal gradients to be estimated at the time of granite emplacement (see later).

\section{Thermodynamic constraints on the pressures and temperatures of metamorphism}

The coexisting mineral pairs garnet-biotite and garnet-cordierite have been calibrated as geothermometers by Thompson (1976) and Perchuk et al. (1981) using the partitioning of $\mathrm{Fe}^{2+}$ and $\mathrm{Mg}^{2+}$ between the mineral pairs. The mineral analyses (Table 2) were recalculated for biotite and garnet to determine the proportion of $\mathrm{Fe}^{2+}$ vs $\mathrm{Fe}^{3+}$; in most instances it was present solely as $\mathrm{Fe}^{2+}$. Considerations of textural equilibrium, and on the basis of the sequence of mineral reactions, the coexisting garnet $\left(\mathrm{M}_{2}\right)$ and biotite in the layered schist are probably in equilibrium, superceding any possible equilibrium associated with the breakdown of cordierite during $\mathrm{M}_{1}$. The temperatures calculated by the two methods are presented in Table 3. The temperatures derived from the mica schist coincide with the temperature estimates for $\mathrm{M}_{1}$ determined by reaction (b) in the layered schist (c.f. Fig. 5).

Although it is hazardous to draw rigorous conclusions, especially when the temperature difference between $M_{1}$ and $M_{2}$ is not large and probably within the range of experimental error, this does suggest that the biotite in the layered schist did not achieve complete equilibrium during $\mathrm{M}_{2}$ and that there is a significant relict component, formed during $\mathrm{M}_{1}$, present in the biotite during $\mathrm{M}_{2}$. Alternatively, the biotite has re-equilibrated in a later metamor- 
Table 2. Sample mineral analyses from the layered schist $(1,2,3)$ and mica schist $(5,6,7)$ which form the basis of the thermodynamic calculations.

\begin{tabular}{lrrrrrrrrrr}
\hline \multicolumn{10}{c}{ Garnet } \\
\hline Sample & \multicolumn{1}{c}{$\begin{array}{c}1 \\
\text { rim }\end{array}$} & \multicolumn{1}{c}{$\begin{array}{c}1 \\
\text { core }\end{array}$} & \multicolumn{1}{c}{2} & \multicolumn{1}{c}{3} & \multicolumn{1}{c}{$\begin{array}{c}5 \\
\text { rim }\end{array}$} & $\begin{array}{c}5 \\
\text { core }\end{array}$ & $\begin{array}{c}6 \\
\text { rim }\end{array}$ & $\begin{array}{c}6 \\
\text { core }\end{array}$ & $\begin{array}{c}7 \\
\text { rim }\end{array}$ & $\begin{array}{c}7 \\
\text { core }\end{array}$ \\
\hline $\mathrm{MgO}$ & 3.0609 & 3.5851 & 3.1647 & 2.4111 & 2.8571 & 3.5171 & 2.8990 & 3.6136 & 2.9712 & 4.3374 \\
$\mathrm{FeO}$ & 35.2163 & 34.8157 & 34.5730 & 35.2969 & 33.4877 & 33.9361 & 33.0676 & 33.8262 & 37.0936 & 34.1924 \\
$\mathrm{CaO}$ & 1.1942 & 1.0484 & 1.1130 & 1.2352 & 1.9605 & 1.4410 & 1.1824 & 1.2416 & 0.9059 & 0.8852 \\
$\mathrm{MnO}$ & 3.0200 & 2.4936 & 3.0485 & 3.2152 & 3.2108 & 2.9635 & 4.1300 & 2.5147 & 1.6153 & 1.2665 \\
$\mathrm{Al}_{2} \mathrm{O}_{3}$ & 20.8408 & 20.8408 & 21.5657 & 21.5591 & 21.0324 & 21.5716 & 21.3448 & 21.1847 & 21.4311 & 21.9454 \\
$\mathrm{SiO}_{2}$ & 37.1696 & 37.6078 & 37.8396 & 37.7590 & 37.9209 & 37.3402 & 37.1366 & 36.9192 & 37.3461 & 37.1739 \\
\hline $\mathrm{Total}$ & 100.5018 & 100.3914 & 101.3045 & 101.4765 & 99.4694 & 100.7695 & 99.7604 & 99.3000 & 101.3632 & 99.8008 \\
\hline
\end{tabular}

\begin{tabular}{|c|c|c|c|c|c|c|c|}
\hline \multicolumn{8}{|c|}{ Biotite } \\
\hline Sample & $\begin{array}{c}1 \\
\text { external }\end{array}$ & $\begin{array}{c}1 \\
\text { inclusion }\end{array}$ & 2 & 3 & 5 & 6 & 7 \\
\hline $\mathrm{MgO}$ & 9.1160 & 13.0086 & 9.4423 & 9.6511 & 10.3593 & 9.1042 & 9.2365 \\
\hline $\mathrm{FeO}^{*}$ & 19.1154 & 13.7217 & 18.7241 & 19.1338 & 18.8058 & 19.3406 & 18.0295 \\
\hline $\mathrm{MnO}$ & - & 0.2298 & - & - & - & 0.2409 & - \\
\hline $\mathrm{TiO}_{2}$ & - & 2.3297 & 2.3817 & 2.4312 & 2.4864 & 2.6257 & 4.5596 \\
\hline $\mathrm{K}_{2} \mathrm{O}$ & 9.0696 & 0.4940 & 8.6117 & 9.0369 & 8.7338 & 9.4012 & 9.2431 \\
\hline $\mathrm{Na}_{2} \mathrm{O}$ & - & 1.7234 & - & - & - & - & - \\
\hline $\mathrm{Al}_{2} \mathrm{O}_{3}$ & 19.7368 & 20.6651 & 20.0830 & 19.9873 & 18.9716 & 19.5083 & 17.7146 \\
\hline $\mathrm{SiO}_{2}$ & 36.1937 & 39.2376 & 36.8623 & 36.7962 & 36.2995 & 34.3232 & 35.0056 \\
\hline Total & 93.2315 & 91.4099 & 96.1051 & 97.0365 & 95.6564 & 94.5441 & 93.7889 \\
\hline \multicolumn{8}{|c|}{ Plagioclase } \\
\hline Sample & \multicolumn{2}{|c|}{1} & 2 & 3 & 5 & 6 & 7 \\
\hline $\mathrm{CaO}$ & \multicolumn{2}{|c|}{6.5747} & 6.2745 & 6.2027 & 4.8131 & 7.3006 & 4.6073 \\
\hline $\mathrm{Na}_{2} \mathrm{O}$ & \multicolumn{2}{|c|}{7.4480} & 8.2111 & 7.8716 & 8.6855 & 7.4944 & 8.7867 \\
\hline $\mathrm{K}_{2} \mathrm{O}$ & \multicolumn{2}{|c|}{-} & 0.1762 & 0.1534 & - & 0.1879 & 0.2341 \\
\hline $\mathrm{Al}_{2} \mathrm{O}_{3}$ & \multicolumn{2}{|c|}{25.7114} & 25.1022 & 24.6287 & 24.0339 & 25.4213 & 23.6391 \\
\hline $\mathrm{SiO}_{2}$ & \multicolumn{2}{|c|}{60.3760} & 60.5486 & 61.6978 & 62.8223 & 58.8647 & 63.0396 \\
\hline Total & \multicolumn{2}{|c|}{100.1101} & 100.3126 & 100.5542 & 100.3548 & 99.2689 & 100.3068 \\
\hline
\end{tabular}

\begin{tabular}{lrrr}
\hline \multicolumn{4}{c}{ Cordierite } \\
\hline Sample & \multicolumn{1}{c}{1} & \multicolumn{1}{c}{2} & \multicolumn{1}{c}{3} \\
\hline $\mathrm{MgO}$ & 7.9584 & 7.9473 & 7.6737 \\
$\mathrm{FeO}^{*}$ & 8.6136 & 8.3735 & 8.5725 \\
$\mathrm{Al}_{2} \mathrm{O}_{3}$ & 33.0211 & 32.8463 & 33.5964 \\
$\mathrm{SiO}_{2}$ & 49.0182 & 48.9025 & 48.1130 \\
\hline Total & 98.6113 & 98.0696 & 97.9556 \\
\hline
\end{tabular}

* Total $\mathrm{Fe}$ as $\mathrm{FeO}$

\begin{abstract}
Mineral analyses were carried out on polished, carboncoated thin sections, using a Cambridge Instruments Microscan 5 X-ray Microanalyser Energy Dispersive System (EDS). Operating conditions were: accelerating potential $20 \mathrm{kV}$, probe current $3 \times 10^{-9}$ amps, count time (depending on the phase analysed) $50-200$ seconds.
\end{abstract}

phic event and records a lower temperature (c.f. Campbell 1980). Another possible explanation may be that since the temperatures for $\mathrm{M}_{1}$ and $\mathrm{M}_{2}$ are similar (and element partition coefficients will be similar in the case of a tempera- ture controlled $\mathrm{K}_{\mathrm{D}}$ ), $\mathrm{M}_{2}$ has had little effect on the biotite composition formed during $\mathrm{M}_{1}$. The corollary to this is that almandine production during $\mathrm{M}_{2}$ is dominated solely by further breakdown of cordierite. 
Table 3. Temperatures derived from geothermometric calculations.

\begin{tabular}{|c|c|c|c|c|c|c|c|c|c|}
\hline Specimen & Phase & $\mathrm{X}^{\mathrm{Mg}}$ & Alm & Pyp & Spess & Gross & $\ln K_{\mathrm{D}}$ & $\mathrm{T}_{1}{ }^{\circ} \mathrm{C}$ & $\mathrm{T}_{2}{ }^{\circ} \mathrm{C}$ \\
\hline \multirow{7}{*}{$\begin{array}{c}1 \\
\text { (Sill) }\end{array}$} & Garnet(r) & 0.059 & 81 & 6 & 11 & 2 & & & \\
\hline & Garnet(c) & 0.124 & 77 & 14 & 6 & 3 & & & \\
\hline & $\mathrm{Bt}(\mathrm{i})$ & 0.461 & & & & & $3.3(\mathrm{r})$ & 334 & \\
\hline & & & & & & & $2.5(\mathrm{c})$ & 438 & 400 \\
\hline & $\mathrm{Bt}(\mathrm{e})$ & 0.634 & & & & & $2.6(\mathrm{r})$ & 424 & \\
\hline & & & & & & & $1.8(\mathrm{c})$ & 560 & 540 \\
\hline & Cord & 0.631 & & & & & & & \\
\hline \multirow{3}{*}{$\begin{array}{c}2 \\
\text { (Sill) }\end{array}$} & Garnet & 0.126 & 77 & 13 & 7 & 3 & & & \\
\hline & $\mathrm{Bt}$ & 0.595 & & & & & 2.3 & 466 & 420 \\
\hline & Cord & 0.628 & & & & & & & \\
\hline \multirow{3}{*}{$\begin{array}{c}3 \\
\text { (Sill) }\end{array}$} & Garnet & 0.096 & 79 & 10 & 8 & 3 & & & \\
\hline & $\mathrm{Bt}$ & 0.473 & & & & & 2.1 & 497 & 460 \\
\hline & Cord & 0.620 & & & & & & & \\
\hline \multirow[t]{2}{*}{5} & Garnet & 0.114 & 75 & 11 & 7 & 7 & & & \\
\hline & $\mathrm{Bt}$ & 0.495 & & & & & 2.0 & 515 & 480 \\
\hline \multirow{2}{*}{$\begin{array}{c}6 \\
\text { (Sill) }\end{array}$} & Garnet & 0.116 & 76 & 12 & 9 & 3 & & & \\
\hline & $\mathrm{Bt}$ & 0.484 & & & & & 1.9 & 528 & 500 \\
\hline \multirow{4}{*}{$\begin{array}{c}7 \\
(\mathrm{Ky})\end{array}$} & Garnet(r) & 0.117 & 82 & 12 & 4 & 2 & & & \\
\hline & Garnet(c) & 0.174 & 77 & 17 & 3 & 3 & & & \\
\hline & $\mathrm{Bt}$ & 0.523 & & & & & $2.1(\mathrm{r})$ & 503 & 470 \\
\hline & & & & & & & $1.6(\mathrm{c})$ & 593 & 580 \\
\hline
\end{tabular}

Coexisting aluminosilicate polymorph is noted.

Explanation of symbols:

$\mathrm{X}^{\mathrm{Mg}}=\mathrm{Mg} / \mathrm{Fe}^{2+}+\mathrm{Mg}+\mathrm{Ca}+\mathrm{Mn}$

$\mathrm{K}_{\mathrm{D}}$ = distribution coefficient (for derivation see Perchuk et al. (1981)

$\mathrm{T}_{1} \quad$ derived from Perchuk et al. (1981); $\mathrm{T}_{2}$ derived from Thompson (1976)

Alm almandine, Bt biotite, Cord cordierite, Gross grossular, Ky kyanite, Pyp pyrope, Sill sillimanite, Spess spessartite; c core, e external, i inclusion, $r$ rim.

An estimate of the pressure during $\mathrm{M}_{2}$ can be derived from the Newton and Haselton (1981) barometer, which is calibrated on the basis of coexisting garnet, plagioclase, $\mathrm{Al}_{2} \mathrm{SiO}_{5}$ and quartz using $\mathrm{Ca}$ partitioning between garnet and plagioclase. This is directly analogous to mineral reaction (a) occurring in the layered schists, providing the garnet has an almandine and pyrope component to accommodate the cordierite breakdown, and the Ca present has equilibrated between the anorthite component of the plagioclase and the grossular component of the garnet. This method gives a pressure for $\mathrm{M}_{2}$ of 5.9-7.4 kb (see Table 4; Newton and Haselton (1981) point out that the results should have a
$1 \mathrm{~kb}$ error). If a similar approach is employed for the mica schist, then with coexisting sillimanite $5.2 \mathrm{~kb}$ is estimated, and with coexisting kyanite 4.3 and $5.6 \mathrm{~kb}$ are estimated using rim and core compositions of garnet, respectively (see Table 4); this may suggest that the kyanite grew under pressure conditions between those of $\mathbf{M}_{1}$ and $\mathbf{M}_{2}$. Equilibrium conditions in the mica schist would be governed by the same conditions as for the layered schist. Both approaches show reasonable agreement with the pressures for $\mathrm{M}_{2}$ indicated on Figure 5. The conditions of metamorphism for $\mathrm{M}_{\mathrm{E}}$ to $\mathrm{M}_{\mathrm{L}}$ ' are summarised in Table 5. 
Table 4. Pressures derived from geobarometric calculations.

\begin{tabular}{|c|c|c|c|c|c|c|c|c|c|c|c|}
\hline Specimen & Phase & Alm & Pyp & Gross & Spess & $\mathrm{X}_{\mathrm{Ca}}^{\mathrm{Piag}}$ & $\mathrm{a}_{\mathrm{Gross}}^{\mathrm{Gt}}$ & $\mathrm{a}_{\mathrm{An}}^{\mathrm{Plag}}$ & $\Delta_{\mathrm{A}}^{\nabla}$ & $\mathrm{T}_{\text {(est) }}{ }^{\circ} \mathrm{C}$ & $\mathrm{P} \mathrm{kb}$ \\
\hline \multirow{3}{*}{$\begin{array}{c}1 \\
\text { (Sill) }\end{array}$} & Garnet(r) & 81 & 6 & 2 & 11 & & 0.020 & & 56.6 & $680-730$ & 7.4 \\
\hline & Garnet(c) & 77 & 14 & 3 & 6 & & 0.031 & & 55.5 & $»$ & 6.1 \\
\hline & Plag & & & & & 0.313 & & 0.202 & & & \\
\hline \multirow{2}{*}{$\begin{array}{c}2 \\
\text { (Sill) }\end{array}$} & Garnet & 77 & 13 & 3 & 7 & & 0.031 & & 55.5 & $»$ & 6.1 \\
\hline & Plag & & & & & 0.316 & & 0.200 & & & \\
\hline \multirow{2}{*}{$\begin{array}{c}3 \\
\text { (Sill) }\end{array}$} & Garnet & 79 & 10 & 3 & 8 & & 0.030 & & 55.5 & $"$ & 5.9 \\
\hline & Plag & & & & & 0.303 & & 0.186 & & & \\
\hline \multirow{2}{*}{$\begin{array}{c}6 \\
\text { (Sill) }\end{array}$} & Garnet & 76 & 12 & 3 & 9 & & 0.031 & & 55.55 & $»$ & 5.2 \\
\hline & Plag & & & & & 0.264 & & 0.152 & & & \\
\hline \multirow{3}{*}{$\begin{array}{c}7 \\
(\mathrm{Ky})\end{array}$} & Garnet(r) & 82 & 12 & 2 & 4 & & 0.020 & & 66.94 & $»$ & 5.6 \\
\hline & Garnet(c) & 77 & 17 & 3 & 3 & & 0.031 & & 67.94 & $\gg$ & 4.4 \\
\hline & Plag & & & & & 0.260 & & 0.157 & & & \\
\hline
\end{tabular}

Explanation of symbols:

c core composition $\mathrm{r}$ rim composition

$\mathrm{X}_{\mathrm{Ca}}^{\mathrm{Plag}}=$ mole proportion of $\mathrm{Ca}$ in plagioclase

$\mathrm{a}_{\text {Gross }}^{\mathrm{Gt}}=$ activity of grossular in garnet

$\mathrm{a}_{\mathrm{An}}^{\text {Plag }}=$ activity of anorthite in plagioclase $\}$ derived from formulae in Newton and Haselton (1981)

$\Delta_{\mathrm{A}}^{\bar{\nabla}}=$ partial molar volume change for the reaction: 3 anorthite $=$ grossular + kyanite + quartz $($ Cressey et al. 1978$)$

$\mathrm{T}_{\text {(est) }}$ : derived from Figure $5\left(\mathrm{M}_{2}\right)$

Table 5. T and $\mathrm{P}$ by different methods for different rock types.

From $P-T$ space

\begin{tabular}{ccc}
\hline $\begin{array}{l}\text { Metamorphic } \\
\text { event }\end{array}$ & Layered schist & Mica schist \\
\hline $\mathrm{M}_{\mathrm{E}}$ & $\begin{array}{c}\text { granulite - pyroxene } \\
\text { granulite facies }\end{array}$ & - \\
\hline $\mathrm{M}_{1}$ & $\begin{array}{c}500-600^{\circ} \mathrm{C} \\
\text { c. } 3 \mathrm{~kb}\end{array}$ & - \\
\hline $\mathrm{M}_{2}$ & c. $700^{\circ} \mathrm{C}$ & - \\
& $7.5 \mathrm{~kb}$ & - \\
\hline $\mathrm{M}_{\mathrm{L}}{ }^{\prime}$ & $500-600^{\circ} \mathrm{C}$ & $500-700^{\circ} \mathrm{C}$ \\
& c. $4 \mathrm{~kb}$ & $3-6.5 \mathrm{~kb}$ \\
\hline
\end{tabular}

From thermodynamic calculations

\begin{tabular}{ccc}
\hline $\mathrm{M}_{1}$ & $400-540^{\circ} \mathrm{C}$ & $470-580^{\circ} \mathrm{C}$ \\
\hline $\mathrm{M}_{2}$ & $5.9-7.4 \mathrm{~kb}$ & $4.4-5.6 \mathrm{~kb}$ \\
\hline
\end{tabular}

Possible ideal conditions for $\mathrm{M}_{\mathrm{L}}$ ' in both layered and mica schist would be $655^{\circ} \mathrm{C}$ at $3.7 \mathrm{~kb}$.

\section{Regional correlation of metamorphic conditions}

Quantitative estimates for metamorphic conditions in the Svecokarelides of eastern Finland are not abundant and regional variations in metamorphic grade can only be correlated meaningfully where contemporaneous development can be established. Those that do exist (Campbell et al. 1979; Treloar et al. 1981) do however elaborate on the now untenable idea proposed by Huhma (1975) that the metamorphic grade in the Svecokarelides simply increases from $\mathrm{E}$ to W. Comparison of previous $\mathrm{P}-\mathrm{T}$ estimates with those derived in this study shows that there are broad similarities between the metamorphic conditions around Savonranta and those operative elsewhere, but that important differences do exist in either the timing of the climactic metamorphic event (manifest in their relation- 
ship to deformational events) or the pressures and temperatures reached during comparable events, or both (Table 6).

Metamorphic conditions around Savonranta suggest that the climax of regional metamorphism $\left(\mathrm{M}_{2}\right)$ occurred in association with the $\mathrm{D}_{2}$ deformational phase at about $700 \pm 50^{\circ} \mathrm{C}$ and $7.5 \pm$ $1 \mathrm{~kb}$, and that this superceded a metamorphism $\left(\mathrm{M}_{1}\right)$ associated with $\mathrm{D}_{1}$ at $550 \pm 50^{\circ} \mathrm{C}$ and 3 $\pm 0.5 \mathrm{~kb}$. Subsequent metamorphism is associated with (1) brittle deformational features and the development of chlorite at c. $300^{\circ} \mathrm{C}$ and $2-3 \mathrm{~kb}$, which were connected with ? $\mathrm{D}_{3}$ and $D_{L}\left(M_{3}\right)$ and (2) a late regionally expressed thermal event $\mathrm{M}_{\mathrm{L}}$ ') connected with the emplacement of the porphyritis granite, producing conditions of metamorphism in the order of 600 $\pm 100^{\circ} \mathrm{C}$ and $4 \pm 1.5 \mathrm{~kb}$. If ideal conditions for reactions (e) and (f) prevailed so that muscovite was produced contemporaneously in the mica and layered schists, conditions of metamorphism for $\mathrm{M}_{\mathrm{L}}$ ' would be constrained to about $650^{\circ} \mathrm{C}$ and $3.7 \mathrm{~kb}$.

Certain features of this sequence compare well with those established in the Kaavi district (Fig. 1 inset); there Park (1983 a) gives c. $550^{\circ} \mathrm{C}$ and $3-4 \mathrm{~kb}$ for $\mathrm{M}_{1}$ conditions and $600^{\circ}-680^{\circ} \mathrm{C}$ and $2.5-4 \mathrm{~kb}$ for $\mathrm{M}_{2}$ conditions. However the Savonranta data contrast with the
$600 \pm 50^{\circ} \mathrm{C}$ and $3.5 \pm 1 \mathrm{~kb}$ estimate derived from a post $-\mathrm{D}_{2}$, syn- $\mathrm{D}_{3}$ (possibly syn- $\mathrm{D}_{2 \mathrm{C}}$ ) static cordierite - amphibole assemblage at Outokumpu (Treloar et al. 1981). Possible explanations for this situtation are that $\mathbf{M}_{2}$ is diachronous across the eastern Finnish Svecokarelides and that the waning stages of the $\mathrm{M}_{2}$ metamorphism are not well expressed in the Savonranta district, or that there are local reasons for the metamorphic high, which in relation to the deformational sequence would be syn- $D_{2 C}$ in the Savonranta district. The intrusion of the Maarianvaara granite during $\mathrm{D}_{3}$ and $\mathrm{D}_{4}$ (c.f. van Breemen and Bowes 1977) between Kaavi and Outokumpu may account for this; there is evidence in the same district of granitic material being associated with the end of the $D_{2}$ deformational phase (Park 1983 a).

Metamorphic conditions in the Savonranta and Outokumpu districts were comparable during the development of the pre- $\mathrm{D}_{1}$ quartz veins in both districts (c.f. Koistinen 1981). In addition, the respective associations of $M_{1}-D_{1}$ and $\mathrm{M}_{2}-\mathrm{D}_{2}$ regionally, the dynamothermal expressions of both metamorphic events and the noticeable absence of abundant igneous material associated with $\mathrm{D}_{1}$ and $\mathrm{D}_{2}$ point to an overall relationship with geotectonic evolution. Perhaps controls of depth of burial (beneath a nappe,

Table 6. Comparison of $\mathrm{T}$ and $\mathrm{P}$ in different parts of eastern Finland.

\begin{tabular}{|c|c|c|c|c|}
\hline Metamorphic event & Savonranta & Kaavi & Outokumpu & Heinävaara \\
\hline $\mathbf{M}_{\mathrm{E}}$ & $\begin{array}{c}\text { granulite-pyroxene } \\
\text { granulite facies }\end{array}$ & - & - & - \\
\hline $\mathrm{M}_{1}$ & $\begin{array}{c}500-600^{\circ} \mathrm{C} \\
\text { c. } 3 \mathrm{~kb}\end{array}$ & $\begin{array}{l}\text { High } \mathrm{T}-\text { mid } \mathrm{P} \\
\text { amphibolite facies }\end{array}$ & - & - \\
\hline $\mathrm{M}_{2}$ & $\begin{array}{c}650-700^{\circ} \mathrm{C} \\
\text { c. } 7.5 \mathrm{~kb} \\
-\end{array}$ & $\begin{array}{c}600-680^{\circ} \mathrm{C} \\
2.5-4 \mathrm{~kb} \\
-\end{array}$ & $\begin{array}{c}- \\
600^{\circ} \mathrm{C} \\
3.5 \mathrm{~kb}\end{array}$ & $\begin{array}{l}- \\
-\end{array}$ \\
\hline $\mathrm{M}_{3}$ & $\begin{array}{l}\text { c. } 350^{\circ} \mathrm{C} \\
2-3 \mathrm{~kb}\end{array}$ & $\begin{array}{l}\text { Low amphibolite- } \\
\text { greenschist facies }\end{array}$ & - & $\begin{array}{l}675^{\circ} \mathrm{C} \\
\text { c. } 5 \mathrm{~kb}\end{array}$ \\
\hline $\mathrm{M}_{\mathrm{L}}{ }^{\prime}$ & $\begin{array}{l}\text { c. } 600^{\circ} \mathrm{C} \\
\text { c. } 4.5 \mathrm{~kb}\end{array}$ & - & - & - \\
\hline
\end{tabular}

Kaavi - Park (1983 a); Outokumpu - Treloar et al. (1981); Heinävaara - Campbell et al. (1979). 
c.f. Campbell 1978) and a regional compressional event during $\mathrm{D}_{2}$ were operative.

The regional correlation, however, exhibits some anomalous features. (1) Staurolite is absent around Savonranta; this might be explained by low f. $\mathrm{O}_{2}$ during metamorphism of different rock compositions and this serves to distinguish the area from the Liperi district to the N (Fig. 1 - inset), which exhibits a static staurolite growth in some schists. (2) The Heinävaara district to the NE has a local sillimanite growth that appears to have been controlled by late $\mathrm{D}_{3}$ thrusts, indicating conditions of metamorphism around $675 \pm 25^{\circ} \mathrm{C}$ and $5.0 \pm 0.25 \mathrm{~kb}$ (Campbell et al. 1979). (3) A static garnet growth associated with $\mathrm{D}_{3}$ around Liperi has been recorded by N. M. Clark (pers. comm.). (4) A feature so far unique to the Savonranta district is the late static growth of muscovite associated with the emplacement of the porphyritic granite.

\section{Discussion}

The interpretation that the layered schist is in its present position because of pre- $\mathrm{D}_{1}$ tectonic interdigitation implies that the cordierite-bearing assemblage developed before the pre- $\mathrm{D}_{1}$ deformational event. On this interpretation, the paragenesis of the cordierite-bearing assemblage is assigned to an early thermal event $\left(\mathrm{M}_{\mathrm{E}}\right)$ that took place before the pre- $\mathrm{D}_{1}$ deformational event. A heat source that is compatible with its timing and required temperature is the hot ultramafic magna associated with the Outokumpu ophiolitic assemblage (Park 1983 b), or a hot slab of mantle peridotite involved in the obduction of the Outokumpu and Savonranta nappes. The presence of a segment of the Outokumpu assemblage $6 \mathrm{~km} \mathrm{~N}$ of the layered schist (Fig. 1), presumably as a tectonic slice (? pre- $\mathrm{D}_{1}$ deformation and/or $\mathrm{D}_{1}$ deformation), does not prove that the layered schist is a small tectonic fragment of rock initially in close spatial associa- tion with the Outokumpu assemblage, but neither is it inconsistent with it.

The drop in the geothermal gradient between $\mathrm{M}_{1}$ and $\mathrm{M}_{2}$ is consistent with a crustal model for the Presvecokarelian plate margin that included a fairly constant heat flux but variable tectonic pressure. Increasing tectonic pressure is consistent with a compressive deformational event that characterises $D_{2}$ for the Savonranta district (Halden 1982 a). It is also compatible with increasing depth of burial, which would be a consequence of nappe emplacement (Campbell 1978; Koistinen 1981; Halden 1982 b; Park 1983 a). Increasing pressure during the $\mathrm{M}_{2}$ event in the Savonranta district is probably a product of both mechanisms.

A considerable proportion of the layer-parallel quartzofeldspathic material that constitutes the migmatites in the Savonranta district (Halden 1982 a) is associated with $D_{1}$ and $D_{2}$. The layer-parallel nature of this material is consistent with a regional structural control. Nowhere, however, is there any field evidence that partial melting affected the schists, and this is supported by evidence that the peak of metamorphism was below minimum melt conditions for granite. This suggests that early quartzofeldspathic material is allochthonous, probably having been derived from beneath the present crustal level exposed in the Savonranta district.

The largest volume of granitic material in the Savonranta district is the porphyritic granite. If this approximates to a minimum melt composition (c.f. Halden 1982 b) and was emplaced as a liquid at the crustal level now exposed $(c .12 \mathrm{~km}$ deep), then with the liquid at $c .750^{\circ} \mathrm{C}$, and muscovite growing in schists approximately 2 $\mathrm{km}$ from its contacts a horizontal geothermal gradient of about $50^{\circ} \mathrm{C} / \mathrm{km}$ is indicated. The schistose anisotropy of the host rock would exercise a significant control on this value, depending upon its orientation, but the vertical geothermal gradient would be approximately the same as the horizontal gradient. Excluding the regional component contributed to the $\mathrm{M}_{2}$ 
metamorphic event, the emplacement of the porphyritic granite represents the regional thermal maximum for the Savonranta district during the Svecokarelian orogeny. The granite has been dated at c. 1780 m.y. (Halden 1982 a) suggesting a thermal peak in this district towards or at the end of the Svecokarelian orogeny.

\section{References}

Bowes, D. R., 1976. Tectonics in the Baltic Shield in the period 2000-1500 million years ago. Acta Geol. Pol. $30,355-376$.

Campbell, D. S., 1978. Structural and metamorphic studies in the Svecokarelides, near Tampere, Finland. Unpubl. Ph.D. thesis, University of Glasgow.

-, 1980. Structural and metamorphic development of migmatites in the Svecokarelides, near Tampere, Finland. Trans. R. Soc. Edinburgh Earth Sci. 71, 185-200.

-, Treloar, P. J. \& Bowes, D. R., 1979. Metamorphic history of staurolite-bearing schist from the Svecokarelides near Heinävaara, eastern Finland. Geol. Fören Stockholm Förh. 101, 105-118.

Cressey, G., Schmid, R. \& Wood, B. J., 1978. Thermodynamic properties of almandine-grossular garnet solid solution. Contrib. Mineral. Petrol. 67, 397-404.

Eskola, P., 1915. On the relations between the chemical and mineralogical composition in the metamorphic rocks of the Orijärvi region. Bull. Comm. Géol. Finlande 44.

Evans, B. W., 1965. Application of a reaction-rate method to the breakdown equilibria of muscovite and muscovite plus quartz. Am. J. Sci. 263, 647-667.

Gáal, G., 1972. Tectonic control of some Ni-Cu deposits in Finland. Rep. 24th Int. Geol. Congr. 4, 215-24.

Ghent, E. D., 1976. Plagioclase-garnet- $\mathrm{Al}_{2} \mathrm{SiO}_{5}$-quartz; a potential geobarometer-geothermometer. Am. Mineral. 61, 710-714.

- \& Stout, M. Z., 1981. Geothermometry and geobarometry of plagioclase-biotite-garnet-muscovite assemblages. Contrib. Mineral. Petrol. 76, 92-97.

Halden, N. M., 1982 a. Structural, metamorphic and igneous history of migmatites in the deep levels of a wrench fault regime, Savonranta, eastern Finland. Trans. R. Soc. Edinburgh Earth Sci. 73, 17-30.

-, $1982 \mathrm{~b}$. The development of granites and migmatites in the deep levels of a wrench fault zone, Savonranta, eastern Finland. Unpubl. Ph.D. thesis, University of Glasgow.
Acknowledgements. Thanks are expressed to the Carnegie Trust for the Universities of Scotland for a Carnegie Scholarship and field grants (N.M.H.), to the University of Glasgow for field grants (D.R.B.), to Dr. C. M. Farrow, Dr T. J. Koistinen and Dr A. F. Park for help and discussion and Exploration Department, Outokumpu Oy for their help and support.

Harris, D. M., 1977. Ascent and crystallization of albite and granitic melts saturated with $\mathrm{H}_{2} \mathrm{O}$. J. Geol. 85, 451 -459 .

Holdaway, M. J., 1971. Stability of andalusite and the aluminium silicate phase diagram. Am. J. Sci. 271, 97-131.

— \& Lee, S. M., Fe-Mg cordierite stability in high-grade pelitic rocks based on experimental, theoretical and natural observations. Contrib. Mineral. Petrol. 63, $175-198$.

Huhma, A., 1975. Precambrian rocks of the Outokumpu, Polvijärvi and Sivakkavaara map areas 1:100,000. Otaniemi: Geological Survey of Finland.

Koistinen, T. J., 1981. Structural evolution of an early Proterozoic stratabound $\mathrm{Cu}-\mathrm{Co}-\mathrm{Zn}$ deposit, Outokumpu, Finland. Trans. R. Soc. Edinburgh Earth Sci. 72, 115 $-158$.

Korsman, Kalevi, 1977. Progressive metamorphism of the metapelites in the Rantasalmi - Sulkava area, southeastern Finland. Bull. Geol. Surv. Finland 290, 82 p.

Leake, B. E., 1970. The origin of the Connemara migmatites of the Cashel district. Connemara, Ireland. Q. J. Geol. Soc. London 125, 219-76.

MacQueen, J. A. \& Powell, D., 1977. Relationship between deformation and garnet growth in Moine (Precambrian) rocks of Western Scotland. Bull. Geol. Soc. Am. 88, 235-240.

Miyashiro, A., 1973. Metamorphism and Metamorphism Belts. London: George Allen \& Unwin.

Newton, R. C. \& Haselton, H.T., 1981. Thermodynamics of the garnet-plagioclase- $\mathrm{Al}_{2} \mathrm{SiO}_{5}$-quartz geobarometer. In Newton, R. C., Navrotsky, A. and Wood, B. J. (eds) Thermodynamics of minerals and melts, 131-147. New York: Springer Verlag.

Nykänen, O., 1975. Precambrian rocks of the Kerimäki and Kitee map sheets 1 : 100 000. Otaniemi, Geological Survey of Finland.

Park, A. F., 1983 a. The origin and tectonic setting of serpentinites and related rocks in the Outokumpu assemblage of the Svecokarelides, eastern Finland. Unpubl. Ph.D. thesis, University of Glasgow. 
Park, A. F., 1983 b. Sequential development of metamorphic fabric and structural elements in polyphase deformed sepentinites in the Svecokarelides of eastern Finland. Trans. R. Soc. Edinburgh Earth Sci. 74, 33-60.

Park, A. F. \& Bowes, D. R., 1983. Basement-cover relationships during polyphase deformation in the Svecokarelides of the Kaavi district, eastern Finland. Trans. R. Soc. Edinburgh Earth Sci. 74, 95-118.

Perchuk, L. L., Podlesski, K. K. \& Aaranovich, L. Ya., 1981. Calculation of thermodynamic properties of end member minerals from natural parageneses. In Newton, R. C., Navrotsky, A. and Wood, B. J. (eds) Thermodynamics of minerals and melts, 111-129. New York: Springer Verlag.

Richardson, S. W., Gilbert, M. C. \& Bell, P. M., 1969. Experimental determination of kyanite-andalusite and andalusite-sillimanite equilibria; the aluminium silicate triple point. Am. J. Sci. 267, 259-272.

Seifert, F., 1970. Low temperature compatability relations of cordierite in heplopelites of the system $\mathrm{K}_{2} \mathrm{O}-\mathrm{MgO}-$ $\mathrm{Al}_{2} \mathrm{O}_{3}-\mathrm{SiO}_{2}-\mathrm{H}_{2}$ O. J. Petrol. 11, 73-99.

Steiger, R. H. \& Jäger, E., 1977. Subcommission on Geochronology: convention on the use of decay constants in geo- and cosmochronology. Earth Planet. Sci. Lett. 36, $359-362$.
Treloar, P. J., Koistinen, T. J. \& Bowes, D. R., 1981. Metamorphic development of cordierite-amphibole rocks and mica schists in the vicinity of the Outokumpu ore deposit, Finland. Trans. R. Soc. Edinburgh Earth Sci. 72, 201-215.

Thompson, A. B., 1976. Mineral reactions in pelitic rocks: II. Calculations of some $\mathrm{P}-\mathrm{T}-\mathrm{X}(\mathrm{Fe}-\mathrm{Mg})$ phase relations. Am. J. Sci. 276, 425-454.

Turner, F. J., 1968. Metamorphic petrology. Mineralogical and field aspects. New York: McGraw-Hill.

-, 1981. Metamorphic petrology. Mineralogical, field and tectonic aspects. (2nd edition) New York: McGrawHill.

Vernon, R. H., 1976. Metamorphic processes. Reactions and microstructural development. London: George Allen \& Unwin.

van Breemen, O. \& Bowes, D. R., 1977. Rb-Sr muscovite age of a pegmatite near Sivakkavaara, Finland. Bull. Geol. Soc. Finl. 49, 7-10.

Wyllie, B. W. D., Huang, W. L., Stern, C. R. \& Maaløe, S., 1976. Granitic magmas: possible and impossible sources, water contents, and crystallization sequences. Can. J. Earth Sci. 13, 1009-1017.

Manuscript received, June 6, 1983. 